\title{
We are what others eat
}

\author{
Stephen Hancocks OBE \\ Editor-in-Chief
}

The BDJ Upfront section includes editorials, letters, news, book reviews and interviews. Please direct your correspondence to the News Editor,

Kate Quinlan at BDJNews@nature.com. Press releases or articles may be edited, and should include a colour photograph if possible.

$\mathrm{F}$ ood in Britain has changed enormously in my lifetime and arguably, the majority of that change has taken place in the last 20 years or so. Partly due to greater prosperity, maybe as a result of more travel which has enabled us to sample cuisines from around the world but also no doubt due to the positive influence of the multicultural society in which we live. Although I haven't attempted to do so I imagine it would be possible to make an A to $\mathrm{Z}$ list of international food options, all of which are available in this country.

As dentists many of us, even if not regarding ourselves as 'foodies' do enjoy a healthy range of foods and meals with partners, within families and with friends dining in and out of home. Professionally, we also have a stake in knowing what our patients eat since one major dietary constituent, sugar, of course, remains central to the tooth tissue destruction that we encounter on a daily basis. We have never been shy at delivering healthy eating messages but in all honesty the early attempts at this were somewhat bland - the 'don't eat so many sweets' versions - while we have accepted latterly that a far more sophisticated approach is now needed.

Having stated that, it is somewhat irksome to be all but bypassed, as a profession which has always advocated sugar restraint in the fight against caries, and swept aside by medical and public health gurus who are taking up the cudgel in the name of obesity, diabetes and a range of other life-style mediated conditions. One almost wants to cry 'what about us? we've said this for years and it suited you not to listen.' But that would be bad form.

Woven into this complex tapestry of prevention versus freedom of shopping is society at large and our political masters (and mistresses). There is some dawning recognition that sugar is not necessarily a good thing and that one way of dealing with this is to apply a tax. Albeit in the first instance it is to be on soft drinks, there has to be a sneaking suspicion that once the government realises the tax grab it provides, it may well seek to extent the tariff to other areas. Whether brought about by the realisation of the rising cost of treating obesity and the toll of morbidity through diabetes, or through a more philanthropic sightline is a matter for debate. At least it is a small step in the right direction.

In our quest to curb the excesses of sugar consumption we therefore have three lines of attack. We can lead by personal example,
Despite the immanent sugar tax I am also not sure that as a society we are anywhere near close to or ready to renounce our love affair with the complex carbohydrate. The crux of the matter is the deep cultural insinuation that it has made over centuries into our collective and individual psyche.

I am aware that I have written this previously but I really do not know what it will take before we even consider reducing our dependence on sugar. It is so emotionally entwined in our way of life, our systems of rewards and treats on the one hand and our guilt of denial and abstention on the other that attempting to unravel it, frankly, seems impossible.

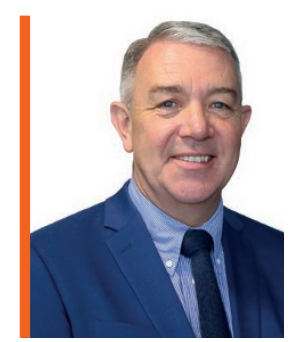

\section{'What about us? We've said this for years and it suited you not to listen...}

although few of our patients will be able to see this at first hand sufficiently to be influenced. We can use our professional position to advise and seek patients' collaboration in their dietary regimes, and we can attempt to influence wider society and government.

To date it has been the middle of this triumvirate that has taken the lion's share of our resources and it is probably correct that this continues to be the case. However, in the time that it has taken us to shift the balance of our approach from oral health 'instruction' to a more consensual, motivational attitude so too has it dawned on us that the only way in which we might achieve this is through behavioural change. And, guess what? We are not really trained in such techniques. I am not sure it bodes well.
Take note, I am not saying that we should give up, or that we should no longer try but I am advocating that we are pragmatic about the options and realistic about the chances of meaningful change.

If we revert to thinking about our own motivations, are we serious about never again in the future giving confectionary and chocolates as gifts? Would we seriously consider abstaining from the treat of a biscuit with coffee, a slice of birthday cake, a sweet snack at the end of a fractious day? If the answer to any of these is 'no' then we, who of all people understand so well the ravages of the disease process, have an uphill struggle convincing anyone else.

I'm just saying. OK?

DOI: $10.1038 /$ sj.bdj.2017.519 